\title{
The Root-Knot Nematode Resistance Gene Mi-1.2 of Tomato Is Responsible for Resistance Against the Whitefly Bemisia tabaci
}

\author{
Gloria Nombela, ${ }^{1}$ Valerie M. Williamson, ${ }^{2}$ and Mariano Muñiz ${ }^{1}$ \\ ${ }^{1}$ Centro de Ciencias Medioambientales (CSIC). Serrano 115 Dpdo. 28006 Madrid, Spain; ${ }^{2}$ Department of Nematology, \\ University of California, Davis 95616, U.S.A.
}

Submitted 23 December 2002. Accepted 21 February 2003.

\begin{abstract}
The tomato gene $M i-1.2$ confers resistance against rootknot nematodes and some isolates of potato aphid. Resistance to the whitefly Bemisia tabaci previously has been observed in $M i$-bearing commercial tomato cultivars, suggesting that $\mathrm{Mi}$, or a closely linked gene, is responsible for the resistance. The response of two biotypes of $B$. tabaci to tomato carrying the cloned $M i$ was compared with that of the isogenic untransformed tomato line Moneymaker. Our results indicate that $\mathrm{Mi}-1.2$ is responsible for the resistance in tomato plants to both $\mathrm{B}$ - and $\mathrm{Q}$ - biotypes. $\mathrm{Mi}$-1.2 is unique among characterized resistance genes in its activity against three very different organisms (root-knot nematodes, aphids, and whiteflies). These pests are among the most important on tomato crops worldwide, making $\mathrm{Mi}$ a valuable resource in integrated pest management programs.
\end{abstract}

Additional keywords: Bemisia argentifolii, Macrosiphum euphorbiae, Meloidogyne spp., Mi gene, plant resistance, transgenic plants.

Plants have evolved sophisticated mechanisms to perceive biotic stresses caused by potential pathogens, and to translate that perception into an adaptive response (Dangl and Jones 2001). Plant resistance, mediated by specific genes, is included among the methods for biological control of pests and diseases (Gabriel and Cook 1990; Whitehead 1998), which is considered one of the most significant approaches to plant health management currently and in the near future (Cook 2000).

Whiteflies are major pests of both greenhouse and open-field horticultural crops. The whitefly Bemisia tabaci (Gennadius) (Hemiptera: Aleyrodidae) causes severe damage to commercial tomato Lycopersicon esculentum L. worldwide. Two biotypes of B. tabaci, which differ in their pattern of random amplified polymorphic DNA polymerase chain reaction (PCR), have been described in Spain (Guirao et al. 1997): the B-biotype, identical to B. argentifolii Bellows \& Perring from California, and the Q-biotype, whose populations lately are increasing in southern Spain. Damage by $B$. tabaci is caused directly through phloem feeding and indirectly by the transmission of 100 different plant viruses to a wide range of plants in tropical and subtropical zones. Tomato yellow leaf curl viruses (TYLCVs), which constitute one of the most important groups of geminiviruses, are transmitted by B. tabaci (Bedford et al. 1994; Blua and Toscano 1994; Brown 1994; Brown and Bird 1992, 1996; Carnero et al. 1990; Markham et al. 1996; Moriones et al. 1993; Schuster et al. 1996).

Corresponding author: Mariano Muñiz; E-mail: mmuniz@ccma.csic.es
The utilization of resistant plants to control B. tabaci recently has increased because whiteflies appear to be resistant to many of the chemicals employed in their control (Russel 1978). A number of commercial cultivars of tomato contain the $\mathrm{Mi}$ gene, which provides resistance to three species of rootknot nematodes (Meloidogyne spp.) (Roberts and Thomason 1986) and some isolates of the potato aphid Macrosiphum euphorbiae (Thomas) (Goggin et al. 2001; Rossi et al. 1998). Studies carried out in our laboratory detected a level of resistance to both B- and Q-biotypes of $\mathrm{B}$. tabaci in several $\mathrm{Mi}$ bearing commercial tomato cultivars, suggesting that $M i$, or a closely linked gene, was implicated in the resistance (Nombela et al. 2000, 2001).

The $M i$ locus has been cloned and found to contain two highly homologous genes, Mi-1.1 and Mi-1.2 (Milligan et al. 1998). Only Mi-1.2 is sufficient to confer resistance to rootknot nematodes (Milligan et al. 1998) and aphids (Rossi et al. 1998). $M i-1.2$ encodes a protein with a nucleotide binding site and leucine rich repeat motifs. Proteins of motif structure make up the largest class of cloned plant resistance genes with specificities against diverse pathogens, including viruses, bacteria, fungi, nematodes, and insects (Dangl and Jones 2001).

In the present work, we evaluate the response of transgenic tomato plants that carry the $M i-1.2$ gene to determine whether this gene is responsible for the resistance to $B$. tabaci previously observed.

\section{RESULTS}

Free-choice assays.

Two experiments were carried out to separately evaluate the preference of each of the B- and Q-biotypes of $\mathrm{B}$. tabaci to the transgenic tomato line 143-11-16-36 and the cultivar Moneymaker. A detailed description of the transgenic plants is given in the Materials and Methods section. In each experiment, 10 replicates of the $M i$-transgenic line were compared with 10 plants of susceptible Moneymaker. The daily infestation rates of both B- and Q-biotypes of B. tabaci were lower on the transgenic tomato line 143-11-16-36 than on Moneymaker at all time points examined (Fig. 1). Mean values of the percentage of adults were significantly $(P<0.05)$ lower on 143-11-16-36 than on Moneymaker (Fig. 2). The final number of pupae on the plants as well as the number of pupae per leaf were significantly greater on Moneymaker than on 143-11-16-36 plants (Fig. 3).

In contrast, in another greenhouse experiment with the Bbiotype at higher temperatures, no statistically significant differences were found between Moneymaker and the transgenic 
line 143-11-16-04 in the averaged numbers of adults daily observed on the plants or in the final numbers of pupae per plant or per leaf. Data from both this and the other free-choice experiment for B-biotype at normal temperatures are shown together in Table 1.

\section{No-choice assays.}

Transgenic tomato line 143-11-16-36 and the control Moneymaker were compared under controlled conditions in two separate experiments, one for each whitefly biotype. The aver-

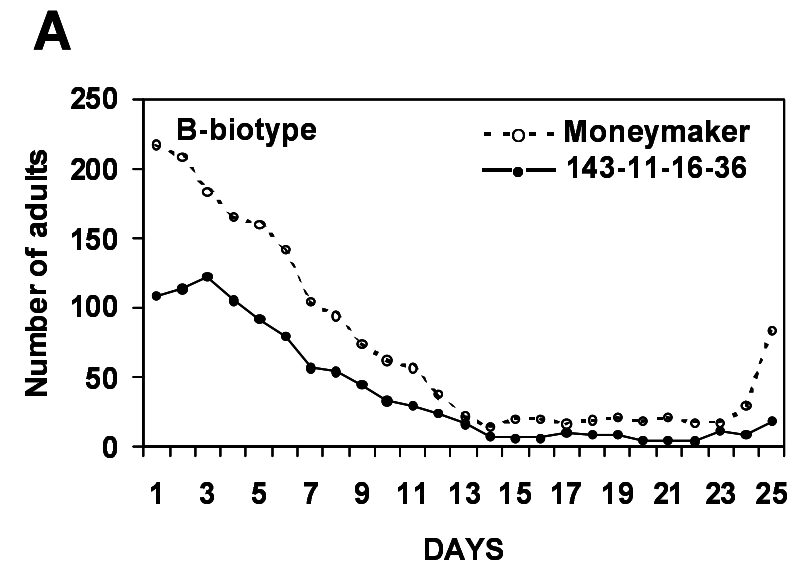

B

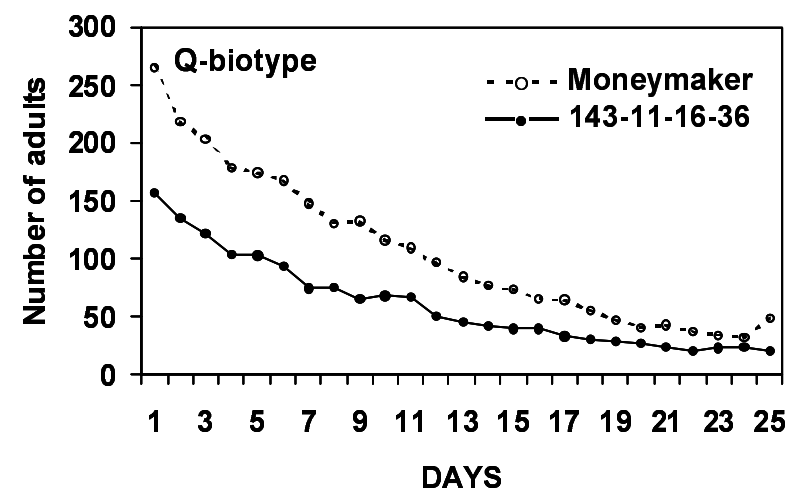

Fig. 1. Infestation rates by whitefly adults daily recorded on tomato transgenic line 143-11-16-36 (+ Mi gene) and tomato cultivar Moneymaker (-Mi gene), during the free-choice assays under greenhouse conditions. A, B-biotype. B, Q-biotype.

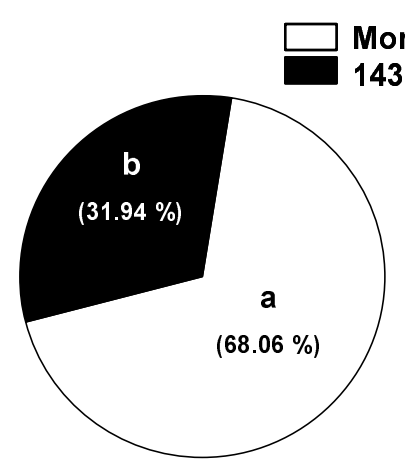

B-biotype
Moneymaker 143-11-16-36

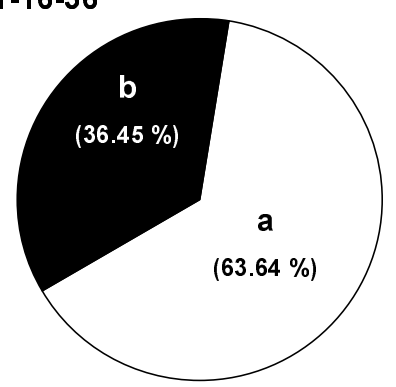

Q-biotype
Fig. 2. Percentages of the B- and Q-biotype adults present on the tomato transgenic line 143-11-16-36 and cv. Moneymaker during the free-choice assays under greenhouse conditions. Percentages with different letters for the same biotype differ significantly $(P<0.05)$ by analysis of variance. aged numbers of L3 and pupae from each biotype, as well as the averaged number of adults from the B-biotype, observed on the plants at the end of the experiment are each significantly lower on line 143-11-16-36 than on Moneymaker (Table 2). The total numbers of insects from the B- and Q-biotype were significantly $(P<0.001$ and $P=0.07$, respectively) lower on 143-11-16-36 than on Moneymaker (Fig. 4).

\section{DISCUSSION}

Results from this study indicate that the $M i-1.2$ gene is responsible for the resistance in tomato plants to both B- and Qbiotypes of $B$. tabaci. The transgenic lines of the present work differ from susceptible Moneymaker only in the presence of a 14.7-kb DNA insert containing $M i-1.2$. This DNA insert has been shown in previous work to be sufficient to confer effective resistance in tomato to root-knot nematodes (Meloidogyne spp.) (Milligan et al. 1998) and to an isolate of the potato aphid Macrosiphum euphorbiae (Rossi et al. 1998).

Multigenic resistance to several insects in tomato has been associated with the presence of glandular trichomes (Heinz and Zalom 1995; Juvik et al. 1994). The resistance to whiteflies regulated by $M i-1.2$ is independent of the presence of glandular trichomes or their exudates on the leaf surface, because type IV or VIc trichomes were absent in all the plants tested in the present and previous experiments (Nombela et al. 2000). In addition, plants from the $M i-1.2$ transgenic line presented similar numbers of type VIa glandular trichomes to those from Moneymaker (data not shown) and, previously, whiteflies often preferred plants bearing greater numbers of this type of trichomes (Nombela et al. 2000).

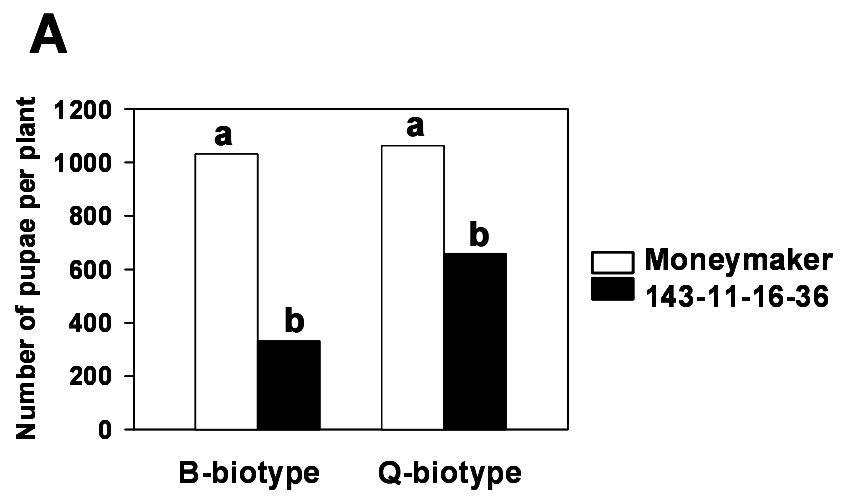

B

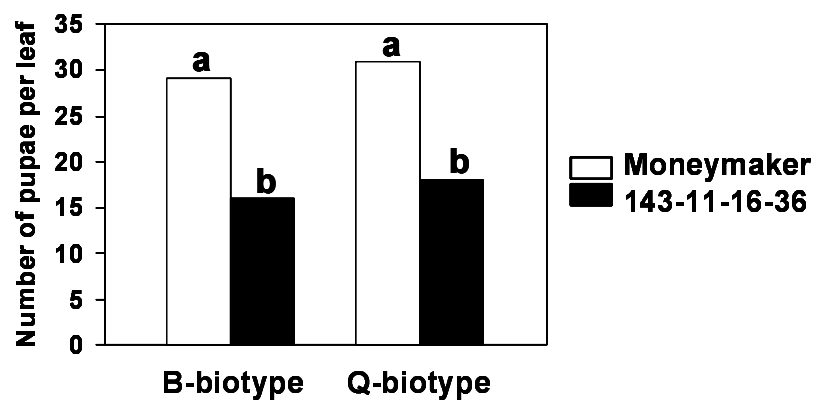

Fig. 3. Pupa production of the B-and Q-biotypes observed at the end of the greenhouse free-choice experiments. Different letters on bars for the same biotype indicate significant $(P<0.05)$ differences by analysis of variance. A, Average number of pupae per plant; $\mathbf{B}$, average number of pupae per leaf. 
Different possibilities have been hypothesized for the way Mi confers resistance in tomato plants (Milligan et al. 1998; Rossi et al. 1998) but the actual mechanisms, even for nematodes or aphids, remain unclear. In addition, the resistance mechanisms may differ for each pest. Mi-1.2 transcripts are present before insect or nematode attack (Heinz and Zalom 1995) and resistance factors in $M i$-bearing tomato plants are detected by $B$. tabaci early during the stylet penetration pathway, indicating that these factors might be present in the leaf epidermis, mesophyl layers, or both, as we previously demonstrated by DC Electrical Penetration Graph analysis (Jiang et al. 2001). These factors inhibit the whiteflies from reaching phloem sieve elements. However, once the stylets reach a sieve element, whitefly behavior did not differ between plants with or without the gene; thus, phloem sap appears to be equally acceptable to the whiteflies. In contrast, resistance to aphids appears to involve differences in length of phloem feeding (Kaloshian et al. 2000).

The present results demonstrated that the Mi-1.2 gene conferred resistance against both B- and Q- biotypes of B. tabaci when tomato plants were 2 months old. We had shown previously that the development of $B$. tabaci on younger tomato plants (two to four true leaves) did not differ in relation to the presence or absence of the $M i$ gene (Pascual et al. 2000), indicating that the activity of this gene against $B$. tabaci is developmentally regulated. $M i$-mediated resistance against aphids is not functional until approximately the fifth week after germination, but resistance against nematodes is functional very early in development (Kaloshian et al. 1995; Martínez de Ilarduya and Kaloshian 2001). Mi-1.2 RNAs in roots and leaves can be detected very early in the development (from 2 weeks of age) of resistant tomato plants; therefore, it is unclear whether $\mathrm{Mi}$ 1.2 is post-transcriptionally regulated differentially in leaves and roots or a developmentally regulated additional factor is required for whitefly resistance, as was hypothesized previously for aphids (Martínez de Ilarduya and Kaloshian 2001).

Comparing the results at normal temperatures with those from the assay at higher temperatures, where no differences due to the presence of $M i-1.2$ were detected, it can be sug-

Table 1. Adults and pupae of the B-biotype of Bemisia tabaci ${ }^{\mathrm{a}}$

\begin{tabular}{lcrc}
\hline $\begin{array}{l}\text { Temperature, } \\
\text { cultivar or line }\end{array}$ & Adults & Pupae/plant & Pupae/leaf \\
\hline High temp & & & \\
Moneymaker & $47.71 \pm 12.14$ & $84.08 \pm 14.86$ & $3.20 \pm 0.69$ \\
143-11-16-04 & $62.43 \pm 17.24$ & $73.33 \pm 16.35$ & $2.30 \pm 0.62$ \\
Normal temp & & & \\
Moneymaker & $72.84 \pm 13.50$ & $1,030.50 \pm 54.01$ & $29.40 \pm 3.47$ \\
143-11-16-36 & $39.08 \pm 8.06$ & $331.18 \pm 33.99$ & $15.92 \pm 1.93$ \\
\hline
\end{tabular}

$\overline{\mathrm{a}}$ Average daily number of adults and final numbers of pupae per plant and pupae per leaf of the B-biotype of Bemisia tabaci from the free-choice experiments under both high and normal temperatures (mean $\pm \mathrm{SE}$ ).

Table 2. L3, pupae, and adults (or empty pupal cases) of the B- and Qbiotype of Bemisia tabaci $^{\mathrm{a}}$

\begin{tabular}{lrrr}
\hline $\begin{array}{l}\text { Biotype, } \\
\text { cultivar or line }\end{array}$ & \multicolumn{1}{c}{ L3 } & \multicolumn{1}{c}{ Pupae } & \multicolumn{1}{c}{ Adults } \\
\hline B-biotype & & & \\
Moneymaker & $21.50 \pm 5.17$ & $29.75 \pm 6.88$ & $29.50 \pm 4.82$ \\
143-11-16-36 & $7.00 \pm 1.86$ & $7.80 \pm 1.65$ & $10.40 \pm 4.14$ \\
Q-biotype & & & \\
Moneymaker & $10.83 \pm 3.49$ & $15.00 \pm 3.84$ & $2.50 \pm 1.09$ \\
143-11-16-36 & $4.22 \pm 1.02$ & $5.33 \pm 1.92$ & $2.22 \pm 1.51$ \\
\hline
\end{tabular}

$\bar{a}$ Numbers of L3, pupae, and adults (or empty pupal cases) of the B- and Q-biotype of Bemisia tabaci on tomato cv. Moneymaker and transgenic line 143-11-16-36, under no-choice conditions (mean $\pm \mathrm{SE}$ ). gested that $M i$ resistance to whiteflies could be temperature dependent, similar to that for root-knot nematodes (Dropkin 1969). Probably, the temperatures over $28^{\circ} \mathrm{C}$ during the first 5 days of our experiment were determinant to break the resistance conferred by $\mathrm{Mi}-1.2$ to the transgenic plants, even though temperature decreased to normal values in other time points of the assay. However, high temperatures also reduced the reproduction rates of $B$. tabaci on both Moneymaker and transgenic plants to very low values. This fact interfered in obtaining ultimate conclusions on the influence of temperature on this resistance, which will require deeper subsequent studies. In relation to aphids, conclusive results on this matter do not exist to date.

From the present findings, $M i-1.2$ can be presented as the first plant resistance gene with activity against three highly divergent organisms (root-knot nematodes, aphids, and whiteflies). The resistance is highly specific and effective against only specific biotypes of potato aphids. It is not effective against the isolates of the green peach aphid, Myzus persicae, that have been tested so far (Goggin et al. 2001). Nevertheless, the pests against which $M i-1.2$ is effective are some of the most important pests of tomato plants worldwide, making $\mathrm{Mi}$ 1.2-regulated resistance a powerful tool in integrated pest management programs for tomato crops.
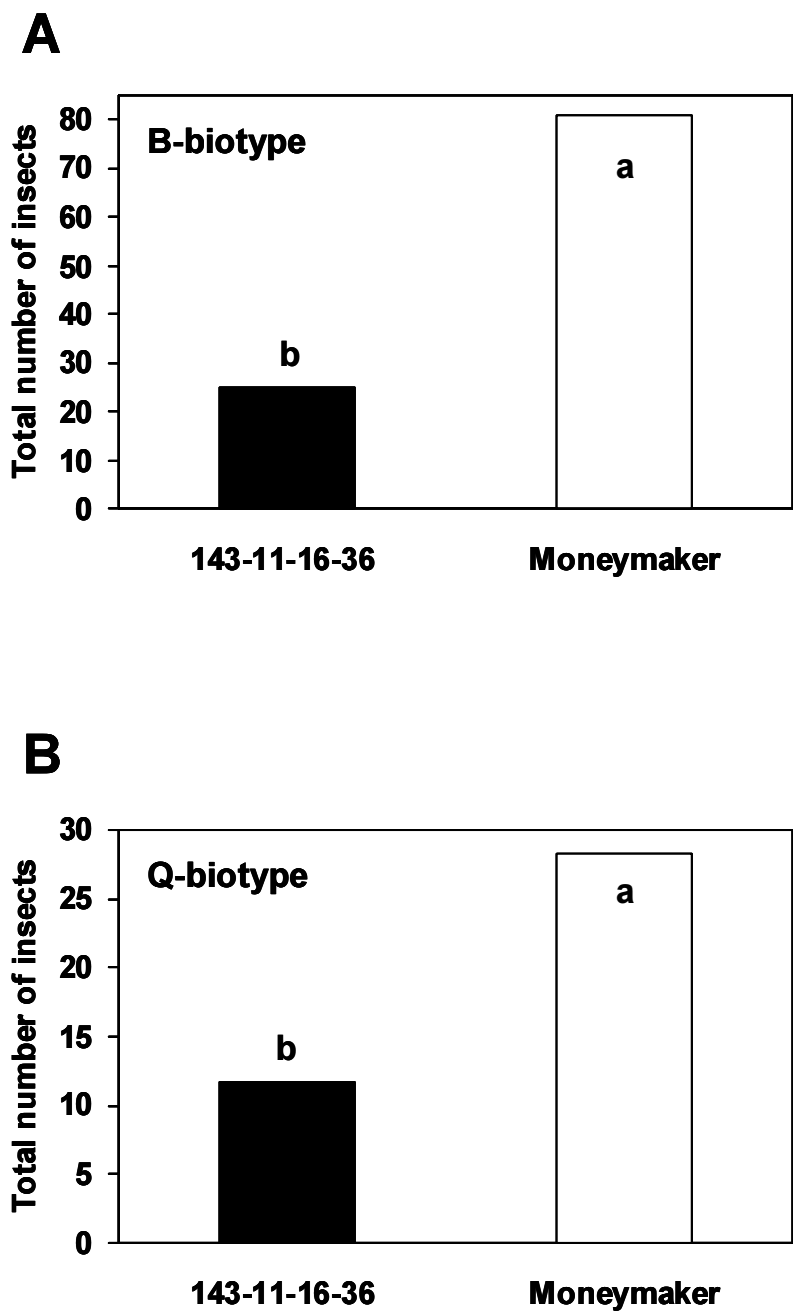

Fig. 4. Average number of insects observed on the plants at the end of the no-choice assay. Total number of insects included L3, pupae, and adult whiteflies, the latter deduced from the number of empty pupal cases. Different letters on bars for the same biotype indicate significant differences by analysis of variance. A, B-biotype $(P<0.001)$; B, Q-biotype $(P=$ $0.073)$. 


\section{MATERIALS AND METHODS}

Transgenic plants.

Susceptible tomato plants of cultivar Moneymaker were transformed with a 14.7-kb tomato genomic fragment carrying the gene Mi-1.2 (Milligan et al. 1998). Progeny tests were carried out and a line homozygous for the introduced $M i$ gene was identified by PCR using primers C1/2 and C1S1. Seed were expanded by Seminis Seed Company (Woodland, CA, U.S.A.) to produce T3 lines. Among them, lines 143-11-16-36 and 14311-16-04 were selected for the present work.

\section{Insect material.}

B. tabaci adults from both the B- and Q-biotypes were used in the experiments. A population of each biotype had been reared on tomato cv. Río Fuego for more than 30 generations. For the experiment at high temperatures, only the B-biotype was used.

\section{Free-choice assays.}

Tomato seed were germinated in a climatic chamber maintained at a temperature regime of 25 and $16^{\circ} \mathrm{C}$ and photoperiod of 16 and $8 \mathrm{~h}$ (light and dark, respectively), and a relative humidity $(\mathrm{RH})$ of 68 to $75 \%$. Plants were grown in a 1:1 soil/perlite mixture in 1-liter plastic pots irrigated with water every other day. When plants were 2 months old, they were transferred to an insect-free greenhouse and randomized in a complete block design at 23 and $16^{\circ} \mathrm{C}$ (light and dark, respectively) and 71 to $88 \% \mathrm{RH}$. Each plant was equidistant from the adjacent pots and the distance among plants was enough to prevent plants from touching each other. Three days later, plants were infested with whiteflies by releasing approximately 2,000 7-day-old mature adults from a point in the center of the place where the benches with the plants were located. After 7 days, the numbers of adult whiteflies were counted daily in situ on all leaves of every plant until the emergence of new adults ( 25 days). Counts were made early in the morning before the adults became active. Three days after the beginning of emergence of new adults, the total numbers of pupae and empty pupal cases on all leaves of every plant were recorded.

Numbers of pupae were $\log _{10}(x+1)$ transformed and analyzed with a one-way analysis of variance (ANOVA) (Statistica version 4.5 [1994] for the Windows Operating System, reference for statistical procedures; Statsoft, Tulsa, OK, U.S.A.). Proportions (p) of B. tabaci daily infestation were transformed to arcsine $(\mathrm{p} / 100)^{0.5}$ before analysis.

Another similar free-choice assay, where temperatures rose to higher values, was considered for comparison. The averaged temperature in the greenhouse during the 21 days of this

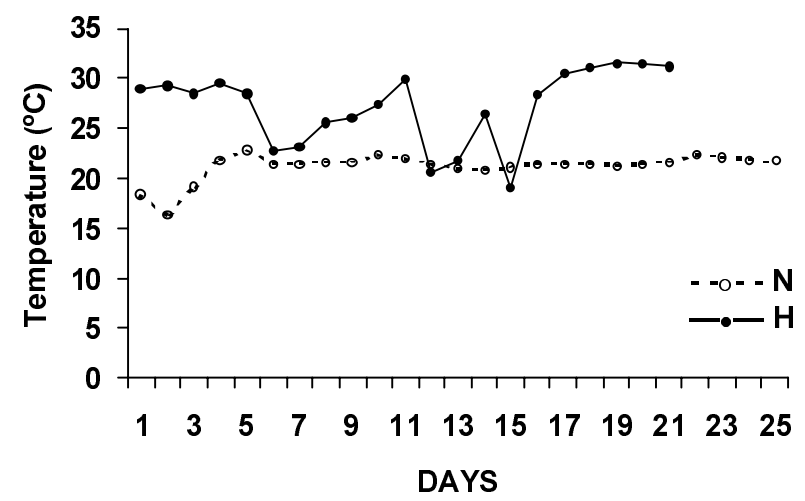

Fig. 5. Averaged daily temperatures recorded in the greenhouse during the two free-choice experiments with the B-biotype carried out under normal $(\mathrm{N})$ and high $(\mathrm{H})$ temperatures, respectively. experiment was $27.20^{\circ} \mathrm{C}$. The daily mean temperatures of both, normal and high temperature experiments are given in Figure 5.

\section{No-choice assays.}

Tomato seed were germinated in a climatic chamber at $25^{\circ} \mathrm{C}$ and then maintained at a constant temperature of $22^{\circ} \mathrm{C}$. Plants were grown in perlite in 1-liter plastic pots and irrigated every other week with a nutritive complex 20-20-20 (Nutrichem 60; Miller Chemical, Hanover, PA, U.S.A.) at a concentration of 3 $\mathrm{g}$ per liter. Meanwhile, plants were irrigated with tap water as needed. When plants were 2 months old, 10 plants of each genotype were kept in the climatic chamber for the assay, which was performed at a constant temperature of $24.5^{\circ} \mathrm{C}$, a photoperiod of 16 and $8 \mathrm{~h}$ (light and dark, respectively), and an $\mathrm{RH}$ of 68 to $75 \%$. Three adult female whiteflies were placed on each plant. Every plant was covered with a transparent plastic cylinder closed on its upper part by a nylon mesh to allow ventilation. After 27 days, the number of insects (L3, mature pupae, and adults) on every leaf of each plant was recorded. Number of adults was deduced from the observed number of empty pupal cases. Total numbers of insects were $\log _{10}(x+1)$ transformed and compared by a one-way ANOVA (Statsoft).

\section{ACKNOWLEDGMENTS}

This study was carried out with funding from the Spanish Ministry of Education and Culture-CICYT, Project reference AGF97-1143. The first author was financially supported by the Temporary Trade Program of Researchers (CSIC/95). We thank M. S. Fernández-Casado and F. Torres (CSIC-Madrid) for technical assistance.

\section{LITERATURE CITED}

Bedford, I. D., Briddon, R. W., Brown, J. K., Rosell, R. C., and Markham, P. G. 1994. Geminivirus transmission and biological characterisation of Bemisia tabaci (Gennadius) biotypes from different geographic regions. Ann. Appl. Biol. 125:311-325.

Blua, M. J., and Toscano, N. 1994. Bemisia argentifolii (Homoptera: Aleyrodidae) development and honeydew production as a function of cotton nitrogen status. Environ. Entomol. 23:317-321.

Brown, J. K. 1994. Current status of Bemisia tabaci as a pest and virus vector in world agroecosystems. FAO Plant Prot. Bull. 42:3-32.

Brown, J. K., and Bird, J. 1992. Whitefly-transmitted geminiviruses and associated disorders in the Americas and the Caribbean basin. Plant Dis. 76:220-225.

Brown, J. K., and Bird, J. 1996. Introduction of an exotic whitefly (Bemisia) vector facilitates secondary spread of jatropha mosaic virus, a geminivirus previously vectored exclusively by the "jatropha" biotype. Pages 351-353 in: Bemisia 1995: Taxonomy, Biology, Damage, Control and Management. D. Gerling, and T. Mayer, eds. Intercept Ltd., Andover, Hants, U.K.

Carnero, A., Montesdeoca, M., Pérez, F., Silverio, A., and Rodríguez, P. 1990. Presencia de Bemisia tabaci (Genn.) en cultivos comerciales de hortícolas y ornamentales en la isla de Tenerife (Islas Canarias). Cuadernos Fitopatol. 25:176-180.

Cook, R. J. 2000. Advances in plant health management in the twentieth century. Annu. Rev. Phytopathol. 38:95-116.

Dangl, J. L., and Jones, J. D. G. 2001. Plant pathogens and integrated defence responses to infection. Nature 411:826-833.

Dropkin, V. H. 1969. The necrotic reaction of tomatoes and other hosts resistant to Meloidogyne: reversal by temperature. Phytopathology 59:1632-1637.

Gabriel, C. J., and Cook, R. J. 1990. Biological control-the need for a new scientific framework. BioScience 40:204-206.

Goggin, F. L., Williamson, V. M., and Ullman, D. E. 2001. Variability in the response of Macrosiphum euphorbiae and Myzus persicae (Hemiptera: Aphididae) to the tomato resistance gene $M i$. Environ. Entomol. 30:101-106.

Guirao, P., Beitia, F., and Cenis, J. L. 1997. Biotype determination of Spanish populations of Bemisia tabaci (Hemiptera: Aleyrodidae). Bull. Entomol. Res. 87:587-593.

Heinz, K. M., and Zalom, F. G. 1995. Variation in trichome-based resistance on Bemisia argentifolii (Homoptera: Aleyrodidae) oviposition on tomato. J. Econ. Entomol. 88:1494-1502. 
Jiang Y. X., Nombela, G., and Muñiz, M. 2001. Analysis by DC-EPG of the resistance to Bemisia tabaci on an Mi-tomato line. Entomol. Exp. Appl. 99:295-302.

Juvik, J. A., Shapiro, J. A., Young, T. E., and Mutschler, M. A. 1994. Acylglucoses from wild tomatoes alter behaviour and reduce growth and survival of Helicoverpa zea and Spodoptera exigua (Lepidoptera: Noctuidae). J. Econ. Entomol. 87:482-492.

Kaloshian, I., Kinsey, M. G., Williamson, V. M., and Ullman, D. E. 2000. The impact of Meul-mediated resistance in tomato on longevity, fecundity and behavior of the potato aphid, Macrosiphum euphorbiae. Environ. Entomol. 29:690-695.

Kaloshian, I., Lange, W. H., and Williamson, V. M. 1995. An aphid-resistance locus is tightly linked to the nematode-resistance gene, $\mathrm{Mi}$, in tomato. Proc. Natl. Acad. Sci. U.S.A. 92:622-625.

Markham, P. G., Bedford, I. D., Liu, S., Frolich, D. F., Rosell, R., and Brown, J. K. 1996. Pages 69-75 in: Bemisia 1995: Taxonomy, Biology, Damage, Control and Management. D. Gerling, and T. Mayer, eds. Intercept Ltd., Andover, Hants, U.K.

Martínez de Ilarduya, O., and Kaloshian, I. 2001. Mi-1.2 transcripts accumulate ubiquitously in resistant Lycopersicon esculentum. J. Nematol. 33:116-120

Milligan, S. B., Bodeau, J., Yaghoobi, J., Kaloshian, I., Zabel, P., and Williamson, V. M. 1998. The root-knot nematode gene $M i$ from tomato is a member of the leucine zipper-nucleotide binding leucine-rich repeat family of plant genes. Plant Cell 10:1307-1319.

Moriones, E., Arno, J., Accotto, G. P., Noris, E., and Cavallarin, L. 1993. First report of tomato yellow leaf curl virus in Spain. Plant Dis. 77:953.
Nombela, G., Beitia, F., and Muñiz, M. 2000. Variation in tomato host response to Bemisia tabaci (Hemiptera: Aleyrodidae) in relation to acyl sugar content and presence of the nematode and potato aphid resistance gene Mi. Bull. Entomol. Res. 90:161-167.

Nombela, G., Beitia, F., and Muñiz, M. 2001. A differential interaction study of Bemisia tabaci Q-biotype on commercial tomato varieties with or without the $M i$ resistance gene, and comparative host response with the B-biotype. Entomol. Exp. Appl. 98:339-344.

Pascual, S., Avilés, M., Nombela, G., Muñiz, M., and Beitia, F. 2000. Development of Bemisia tabaci (biotype Q) on tomato cultivars with / without the $M i$ gene. Meded. Fac. Landbouwwet. Rijksuniv. Gent 65/2a:291-292.

Roberts, P. A., and Thomason, I. J. 1986. Variability in reproduction of isolates of Meloidogyne incognita and M. javanica on resistant tomato genotypes. Plant Dis. 70:547-551.

Rossi, M., Goggin, F. L. Milligan, S. B., Kaloshian, I., Ullman, D. E., and Williamson, V. M. 1998. The nematode resistance gene $M i$ of tomato confers resistance against the potato aphid. Proc. Natl. Acad. Sci. U.S.A. 95:9750-9754.

Russel, G. E. 1978. Plant Breeding for Pest and Disease Resistance. Huttterworth, London/Boston.

Schuster, D. J., Stansly, P. A., and Polston, J. A. 1996. Expressions of plant damage by Bemisia. Pages 153-165 in: Bemisia 1995: Taxonomy, Biology, Damage, Control and Management. D. Gerling, and T. Mayer, eds. Intercept Ltd., Andover, Hants, U.K.

Whitehead, A. G. 1998. Plant Nematode Control. CAB International, Wallingford, U.K. 